\title{
Helminth fauna of Lebanon Lizard, Phoenicolacerta laevis (Gray, 1838), (Squamata: Lacertidae) from Southern Turkey
}

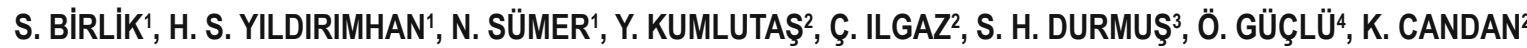 \\ ${ }^{1 *}$ Uludag University, Faculty of Arts and Sciences, Department of Biology, Nilüfer, Bursa, Turkey; ${ }^{2}$ Dokuz Eylül University, \\ Faculty of Science, Department of Biology, 35160, Buca-izmir, Turkey; ${ }^{3}$ Dokuz Eylül University, Faculty of Education, \\ Department of Biology, 35160, Buca-Izmir, Turkey; ${ }^{4}$ Aksaray University, Güzelyurt Vocational School, \\ Department of Plant and Animal Production, 68500, Güzelyurt/Aksaray, Turkey
}

\section{Article info}

Received December 1, 2015 Accepted March 3, 2016

\begin{abstract}
Summary
In the years 2010 and 2014, fifty-four samples of Phoenicolacerta laevis from eight localities in Adana $(n=6)$ and Hatay $(n=48)$ were collected and examined for helminth parasites. New host and locality records were recorded. As a results of present study, three species of Digenea, Sonsinotrema tacapense, Prosthodendrium chilostomum, Brachylaima sp. (metacercaria); two species of Cestoda, Oochoristica tuberculata and Mesocestoides sp. and four species of Nematoda, Skrjabinodon medinae, Spauligodon sp., Thubunaea sp. and a larva of the Ascaridiidae Ascarididae gen. sp. were reported for lizard samples. We document new host records for all of helminth species reported here. Sonsionotrema tacapense (Digenea), and Thubunaea sp. (Nematoda) are recorded for the first time from Turkey. There are, to our knowledge, no reports of helminths for $P$. laevis in Turkey and also from its range.

Keywords: Phoenicolacerta laevis; Digenea; Cestoda; Nematoda; helminth; Turkey
\end{abstract}

\section{Introduction}

Turkey is situated in junction point of fauna unit from several different origins and has 157 amphibia and reptilia species with as rich as continental Europe (Baran \& Atatür, 1998; Baran et al., 2012). However, the literature dealing with the parasitic fauna of the Turkey still contains little information on helminths of lizards. Reptiles are commonly infected by a wide range of parasites, serving either as their definitive or intermediate hosts (Azhar, 2010). However, despite the great diversity of the Lacertidae lizards relatively few species have been surveyed for helminths.

Across the world, there are several studies on helminth fauna of some Lacertid lizards especially from Palearctic region. These species and localities are; Lacerta agilis from Poland (Lewin, 1992a) and Zootaca vivipara (Lewin, 1992b), Lacerta agilis from Palaearctic (Sharpilo et al., 2001); Lacerta viridis from Bulgaria (Biserkov \& Kostadinova, 1998); Lacerta viridis and Podarcis mu- ralis from Bulgaria (Kirin, 2002), Podarcis pityusensis from Spain (Hornero \& Roca, 1992), Lacerta schreiberi from Spain (Roca \& Ferragut, 1989); Podarcis pityusensis and Podarcis lilfordi from Spain (Roca \& Hornero, 1994), Lacertidae family from Spain (Roca \& Lluch, 1988), Lacerta agilis from Romania (Mihalca et al., 2007), Podarcis bocagei and Podarcis carbonelli from Portugal (Galdon et al., 2006), Zootaxa vivipara from Spain (Sanchis et al., 2000), Gallotia caesaris gomerae and Gallotia caesaris caesaris from Spain (Martin \& Roca, 2004), Podarcis vaucheri from Algeria (Carretero et al., 2011). There are some helminth parasite studies in Turkey especially for lacertid lizards. These species are European Green Lizard, Lacerta viridis (Schad et al., 1960); Crimean Wall Lizard Podarcis tauricus (Schad et al., 1960); Dwarf Lizard, Parvilacerta parva (Saygı \& Olgun, 1993); Danford's Lizard, Anatololacerta danfordi (Gürelli et al., 2007), Balkan Emerald Lizard, Lacerta trilineata (Yıldırımhan et al., 2011); Pleske's Racerunner-Transcaucasian Racerunner, Eremias pleskei, Strauch's Rac- 
erunner, Eremias strauchi, Suphan Racerunner, Eremias suphani (Düsen et al. 2013), Anatolian Lizard, Apathya cappadocica, (Birlik et al., 2015), Spiny-Tailed Lizard, Darevskia rudis (Roca et al., 2015a), and Uzzel's lizard Darevskia uzzelli, Bendimahi Lizard D. bendimahiensis and Van Lizard D. sapphirina (Roca et al., 2015b). Lebanon lizard Phoenicolacerta laevis occurs in southern and western Turkey (Vilayets Hatay, Adana, Mersin, Kahramanmaraş, Osmaniye, Antalya, Muğla and İzmir), western Syria, throughout Lebanon (where widespread, including on Palm Island), northern Israel and northwestern Jordan (Ilgaz et al., 2016). It has a plumped body with a total length up to $25 \mathrm{~cm}$. Head and body is flattened dorso-ventrally. The ground color of dorsum is greenish brown with dark markings. The chin and neck are red or yellowish-red color in spring (Baran \& Atatür, 1998; Baran et al., 2012). It is found up to $1,800 \mathrm{~m}$ above sea level (asl). In suitable habitats, the population density is so high. This reasonably adaptable species is found in rocky forested areas, in meadows, in gardens, on walls of houses and in orchards. It is an egg-laying species. The species prefers humid habitats in oak forests, gardens and valleys. More recent, Tamar et al. (2015) conducted the most compressive molecular study based on both mitochondrial and nuclear gene fragments (covering 12S rRNA, cytb, MC1R and ACM4) on genus Phoenicolacerta. They found high levels of undescribed diversity within $P$. laevis which necessitate a thorough revision but did not do any taxonomical rearrangement. For that reason, we can accept the host species used in the present study as $P$. laevis now. Recently, studies of helminth parasites from lizards have been started to increase gradually in defined geographical areas but studies on helminth fauna of lizards of the genus Phoenicolacerta are partial and scarce, none for $P$. laevis. Thus, this work represents an opportunity to know for the first time helminth communities parasitizing $P$. laevis from Turkey.

\section{Material and Methods}

In November 2010 and between April and May 2014, 54 P. laevis $(24$,, 31 J) mean snout-vent length $=68,57 \pm 11,46 \mathrm{~mm}$, with a range from 46.0 to $87.0 \mathrm{~mm}$, were collected by hand from Hatay and Adana, Turkey: Kırıkhan- Hatay $\left(36^{\circ} 29^{\prime} \mathrm{N}, 36^{\circ} 21^{\prime} \mathrm{E}, 151 \mathrm{~m}\right.$ elevation, on 2 November 2010, n=19), Döver Village, Harbiye, Hatay $\left(36^{\circ} 06^{\prime} \mathrm{N}, 36^{\circ} 07^{\prime} \mathrm{E}, 251\right.$ m elevation, on 2 May 2014, $\left.\mathrm{n}=12\right)$, Yenişehir Lake, Reyhanlı, Hatay $\left(36^{\circ} 14^{\prime} \mathrm{N}, 36^{\circ} 34^{\prime} \mathrm{E}, 179 \mathrm{~m}\right.$ elevation, on 1 May 2014, n=1), Ceylanlı, Kırıkhan, Hatay $\left(36^{\circ} 33^{\prime} \mathrm{N}\right.$, $36^{\circ} 21^{\prime} \mathrm{E}, 401 \mathrm{~m}$ elevation, on 1 May 2014, n=1), Çevlik, Samandağ, Hatay $\left(36^{\circ} 07^{\prime} \mathrm{N}, 35^{\circ} 55^{\prime} \mathrm{E}, 28 \mathrm{~m}\right.$ elevation, on 2 May 2014 , $\mathrm{n}=11$ ), Delibekirli Village, Kırıkhan, Hatay ( $36^{\circ} 32^{\prime} \mathrm{N}, 36^{\circ} 19^{\prime} \mathrm{E}$, 550 m elevation, on 1 May 2014, n=4), Köleli Village, Feke, Adana $\left(37^{\circ} 48^{\prime} \mathrm{N}, 35^{\circ} 54^{\prime} \mathrm{E}, 557 \mathrm{~m}\right.$ elevation, on 21 April 2014, n=2), Dağılcak Recreation Area, Kozan, Adana (3732'N, 3550'E, 305 m elevation, on 17 April 2014, n=1), Gedikli Village, Kozan, Adana (37 $30^{\prime} \mathrm{N}, 35^{\circ} 52$ 'E, 398 m elevation, on 27 April 2014, n=3).

The body cavity was opened, and the digestive tract removed. The oesophagus, stomach, small and large intestine and lungs were opened and separetly examined for helminths under a dissecting microscope. Nematodes were killed in hot saline solution, fixed in $70 \%$ ethanol, and mounted in glycerol. For the morphological examination, the helminth species were cleared gradually in glycerin. Digeneans and cestodes were fixed in $70 \%$ ethanol, stained with iron-carmine as described by Georgiev et al., (1986), cleared in clove oil, and mounted in Entellan. Parasites were identified, where possible, to species, and the number and location of individiuals of each species were recorded. Helminth identification was based on keys given by Schmidt (1986), Petter \& Quentin (1976), Yorke \& Maplestone (1926), Yamaguti (1961), Baker (1987), Bray et al. (2008). Helminth voucher specimens were deposited in the helminth collection of Uludag University Science and Art Faculty, Department of Biology, Bursa, Turkey.

\section{Results}

Nine species of helminth parasites were detected in Lebanon Lizard. These species were 3 species of Digenea, Sonsinotrema tacapense, Prosthodendrium chilostomum, Brachylaima sp. (metacercaria); two species of Cestoda, Oochoristica tuberculata and Mesocestoides sp. and four species of Nematoda, Skrjabinodon medinae, Spauligodon sp., Thubunaea sp. and a larva of the Ascaridiidae Ascarididae gen. sp. Of 54 P. laevis $33(61 \%)$ were infected with one or more parasites. Of 54 host lizard 21 (38\%) were infected by any parasite species. Total 278 individuals of nine parasite species were collected from 33 of the 54 Lebanon lizards examined. Of these, three $(9 \%)$ were larval forms not capable of reaching maturity in lizards. There were nine helminth species represented in the lizards but no individual host harbored more than three helminth species. Of the infected lizards, 24 harbored one species of helminth; six harbored two species and three harbored three species. There were $7.72 \pm 0.88(x \pm S E)$ helminth species/infected lizard. Infection prevalence, abundance and mean intensity of the parasites in $P$. laevis were given in Table 1. More than $45 \%$ of the total helminths found belong to a single species, Prosthodendrium chilostomum (Digenea), followed by Skrjabinodon medinae 36\% (Nematoda). All helminths found in P. laevis are new host records.

\section{Digenea: Brachylaimidae \\ Brachylaima Dujardin, 1843 \\ Brachylaima sp. (metacercariae)}

Species of Brachylaima are parasites that often exhibit a triheteroxenous terrestrial life cycle in which molluscs serve as first and second intermediate hosts and amphibians and reptiles may harbor unencysted metaceraria, before reaching the definitive hosts, birds and mammals. Adults are parasites of the small intestine of birds and mammals (Yamaguti, 1958) metacercaria in Reptilia (Roca et al., 1989, Roca \& Hornero, 1994; Galdon et al., 2006; Roca et al., 2006). We found this species in only one infected host lizard $(3 \%)$ from Hatay province. A total parasite number of this 
Table.1 Prevalence, mean intensity and mean abundance of helminth species found in lizards

\begin{tabular}{ccccc}
\hline Helminth species & Site of infection & Prevalence (\%) & Mean intensity & Mean abundance \\
\hline Digenea & & & & \\
Sonsinotrema tacapense & small intestine & 1.85 & 7 & 0.12 \\
Prosthodendrium chilostomum & small intestine & 7.40 & 31.75 & 2.35 \\
Brachylaima sp. & small intestine & 1.85 & 1 & 0.01 \\
Cestoda & & & & \\
Mesocestoides sp. (larvae) & body cavity & 1.85 & 1 & 0.01 \\
Oochoristica tuberculata & small intestine & 3.7 & 2.5 & 0.09 \\
Nematoda & & & & 0.5 \\
Spauligodon sp. & caecum & 16.6 & 3.11 & 1.87 \\
Skrjabinodon medinae & large intestine & 48.14 & 3.88 & 0.12 \\
Thubunaea sp. & stomach & 1.85 & 7 & 0.01 \\
Ascarididae gen. sp. & small intestine & 1.85 & 1 & \\
\hline
\end{tabular}

species was one. Acccording to the literature, this is the third report of metacercaria of Brachylaima from Turkey; Other reported hosts: Lacerta trilineata (Yıldırımhan et al., 2011) and Chalcides ocellatus (Incedogan et al., 2014). P. laevis represents a new host record for the genus Brachylaima.

\section{Trematoda: Lecithodendriidae}

Sonsinotrema tacapense (Sonsino, 1894) Balozet \& Callot, 1938

Specimens of this digenetic trematode were detected in the small intestine of $P$. laevis from only one of the localities studied. A total parasite number were seven in one host from Kırıkhan, Hatay province. There are no reports from Turkey for this species. This is the first report of $S$. tacapense from Turkey. $P$. laevis is a new host record for this species.

\section{Prosthodendrium chilostomum (Mehlis, 1831)}

Lecithodendriid flukes form the bulk of the intestinal parasites of bats, and of these, a large part belong to the genus Prosthodendrium Dollfus, 1931. This trematode attained sexual maturity in its intermediate host. It was reported from Lacerta viridis and Zootaca vivipara (Sharpilo, 1976) from Ukraine. There are no reports from
Turkey for this species. We found this species in the small intestine. A total parasite number were 120 in four hosts from Hatay province. This is the first report of $P$. chilostomum from Turkey. $P$. laevis is a new host record for this species. The most abundant helminth that was found parasitizing P. laevis was Pr. chilostomum, with a mean intensity of 31.75 parasites per host.

\section{Cestoidea \\ Cyclophyllidea: Mesocestoididae \\ Mesocestoides sp. Vaillant, 1863}

Adults are parasites of birds and mammals, and according to Witenberg (1934) the first mention of tetrathyridium as accidental or paratenic parasites of lizards was Lacerta viridis and Podarcis muralis listed by Rudolphi (1819). The genus Mesocestoides is cosmopolitan (Schmidt, 1986). Tetrathyrida is frequently found in the body cavities of amphibians, reptiles, and rodents (Padgett \& Boyce, 2004).

In our study, only one tetrathyrida was collected from one of 33 infected host lizard (3\%). P. laevis represents fourth host record for the genus Mesocestoides from Turkey. The first report of this genus was in the Lacerta trilineata from Bursa, Turkey (Yıldıımhan et al., 2011). The second report was Anatolalacerta danfordi from 
Western Turkey (Gürelli et al., 2007). The third report was Apathya cappadocica from Turkey (Birlik et al., 2015). P. laevis represents new host record for tetrathyridia of Mesocestoides.

\section{Cestoidea \\ Cyclophyllidea: Anoplocephalidae \\ Oochoristica tuberculata}

(Rudolphi, 1819) Lühe, 1898

In our study, this species was observed in only two hosts (6\%). This species was reported from Paralaudakia caucasia (Yıldırımhan et al., 2006), Lacerta trilineata (Yıldırımhan et al., 2011), Chalcides ocellatus (Incedogan et al., 2014) and Apathya cappadocica (Birlik et al., 2015) from several localities in Turkey. This report is the fifth for 0 . tuberculata from reptiles in Turkey. We document herein a new host record for 0 . tuberculata, the first report of a cestode parasite from $P$. laevis.

\section{Spirurida: Physalopteridae \\ Thubunaea Seurat, 1914 \\ Thubunaea sp.}

According to Bursey \& Goldberg (1991) there are at present 17 species of Thubunaea including the parasites of reptiles. Adult worms are found in the stomach or intestine of lizards and snakes. The physalopterines are usually found firmly attached to the gastric mucosa with the aid of large dentate pseudolabia and a collarette which presses into the mucosa. There is only limited information on species in reptiles. In our study, only female specimens have been found. So this specimen was identified at a genus level. When males are found, the length of the spicule, in association with other morphometric data, is a useful comparative character for specific identification.

We found this parasite species in only one host lizard (1.85\%) from Samandağ, Hatay province. A total parasite number of this parasite species was seven. Acccording to the literature, there are no records of Thubunaea sp. from Turkey. This helmint species is a new helmint record for Turkey. Also, P. laevis is a new host record for Thubunaea sp.

\section{Oxyurida: Pharyngodonidae \\ Skrjabinodon (Inglis, 1968) \\ Skrjabinodon medinae (Garcia Calvente, 1948)}

Skrjabinodon medinae is a cosmopolitan parasite of reptiles (Inglis, 1968; Petter \& Quentin 1976). Small cylindrical nematodes, evident sexual dimorphism, males approximately one-fourth length of female. Lateral alae present in males, absent in females. Females with vulva near esophageal bulb. Several morphological characteristics noted by different authors (Skrjabin et al., 1960; Inglis, 1968; Petter \& Quentin 1976), as last pair of papillae not rosette-shaped and the absence of caudal alae in the male, indicate the genus Skrjabinodon Inglis, 1968. S. medinae posseses four pairs of cloacal papillae, including two pairs of postcloacal papillae (Hornero \& Roca 1992).
We found this parasite species in twenty-six infected host lizards (78\%) from Adana and Hatay provinces. More than 35\% of the total helminths found belong to Skrjabinodon medinae. This species was the second most abundant helminth that was found parasitizing $P$. laevis with a prevalence of $48.14 \%$ and a mean intensity of 3.88 parasites per host.

A total parasite number of this parasite species was 101. Both male and female specimens have been found. Acccording to the literature, two species of Skrjabinodon Inglis, 1968 have been reported previously from reptiles of Turkey. These species and hosts are Skrjabinodon medinae from Lacerta trilineata (Yıldırımhan et al., 2011), Sk. aegyptiacus from Chalcides ocellatus (Incedogan et al., 2014). This species was reported from Apathya cappadocica (Birlik et al., 2015). This is the third report for Sk. medinae from Turkey. P. laevis is a new host record for $S$. medinae.

\section{Ascaridida: Heterakoidea \\ Ascarididae Baird, 1853 \\ (Undetermined larvae)}

Ascarididae larvae, genera of the Ascarididae often exhibit unique esophageal characters, which when present can be used to identify a larva. Unique characters are generally absent, and it is impractical to assign such larvae to a genus.

In present study, larval forms of helminths have been found in host lizard. This suggests that this lizard is a useful intermediate host for heteroxenous helminth species.

We found this larvae in only one infected host lizard (3\%) from Samandağ, Hatay province. A total parasite number of this larvae was one. Acccording to the literature, Ascarid larva reported from Stellagama stellio from Turkey (Yıldırımhan et al., 2006). This is the second report for this parasite and $P$. laevis represent new host record for larvae assigned to the Ascarididae.

\section{Oxyuroidea: Pharyngodonidae \\ Spauligodon Skrjabin, Schikkhobalova and Lagodovskaja, 1960 \\ Spauligodon sp.}

Species of Spauligodon are separated on the basis of the presence or absence of a spicule, the appearance of the tail, egg morphology, and geographical distribution.

Currently, 50 species are assigned to Spauligodon. Based upon the zoogeographic regions described by Holt et al. (2013) eight from the Afrotropical realm, one from the Australian realm, one from the Madagascan realm, seven from the Nearctic realm, three from the Neotropical realm, three from the Oceanian realm, one from the Oriental realm, 16 from the Palaeractic region, five from the Panamanian realm, and five from the Saharo-Arabian realm. Three species have previously been described in which males have aspinose filamentous tails and a spicule absent, and females have spinose filamentous tails and barrel-shaped eggs, namely, S. atlanticus, S. eremiasi, and S. occidentalis. The location of the vulva can be used to distinguish some species. In S. occidentalis, 
the vulva is anterior to the esophageal bulb. In this study, male specimens have no spicule and aspinose filamentous tail; female specimens have spinose filamentous tail. There are no Spauligodon records about prebulbar vulva location from Palearctic up to now. Advanced studies will be needed about this species.

We found this nematode in nine infected host lizard (27\%) from Samandağ, Hatay province. A total parasite number of this species was 28. Acccording to the literature, there is one record of Spauligodon sp. from Turkey (Saygı \& Olgun, 1993). Also, P. laevis is a new host record for Spauligodon sp.

\section{Discussion}

Studies on the community ecology of parasites of European reptiles, and particularly lacertids, have increased in the last years. (Roca et al., 2012). However, there are 66 species of lizards known from Turkey (Uetz, 2015): one species of Phyllodactylidae, five species of Gekkonidae, one species of Eublepharidae, four species of Agamidae, one species of Chamaeleontidae, two species of Anguidae, one species of Varanidae, 39 species of Lacertidae, nine species of Scincidae and three species of Amphisbaenidae. Up to now, only 10 lizard species from Lacertidae have been investigated for helminth fauna in Turkey.

In our study, the helminth fauna of the studied population of $P$. laevis was rich as helminth biodiversity was concerned but was poor as numbers of helminth were investigated. Most helminth species occured at low prevalence. The low value of prevalence and mean intensity of infection indicate that many members of the helminth infracommunities occur only irregularly and occasionally (Martin \& Roca, 2005). Helminth species have been classified as core and secondary species according to their prevalence $(P)$ : species with prevalence $>30 \%$ redeemed core species and species with $10-30 \%$ prevalence is considered secondary species (Roca, 1993). There is only one core species (prevalence of infeciton $30 \%$ or higher) in helminth population (Skrjabinodon medinae with a prevalence 48.17) so only the Sk. medinae appears to be a common parasite of $P$. laevis. This agrees with the typical pattern of helminth infection in many reptiles, i.e., few species occur frequently, few species occur moderate prevalence and many species are rare (Aho, 1990; Martin \& Roca, 2005). The remaining helminth species can be considered as a secondary species of $P$. laevis. The low richness of helminths and the low prevalence and infection rates found for $P$. laevis might be related to the diet. Our results confirm previous findings, suggesting that small carnivorous reptiles harbor poorer helminth communities than herbivorous ones (Petter \& Quentin, 1976; Martin et al., 2005; Carretero et al., 2006).

In our study, especially for some helminth species obtained from host lizard -for example Thubunaea sp.- if male specimens are found, it will be identified at species level in next studies. It will be same for Ascarididae, too (undetermined larvae).

In summary, we have documented nine new host and four new distributional records for helminths of $P$. laevis. $P$ laevis represents a new host record for each of the parasite species. Two helminth species are reported from Turkey for the first time. We suspect that with additional surveys, particularly those carried out other parts of its range where studies are lacking, additional host and distributional records for its parasites will be potentially reported.

\section{Acknowledgement}

The lizard samples used in this study were collected within the scope of the project supported by TUBITAK (The Scientific and Technological Research Council of Turkey), project number 112 T269.

\section{References}

Aно, J.M. (1990): Helminth communities of amphibians and reptiles: comparative approaches to understanding patterns and processes. In: Esch, G., Busch, A., Aно, J. (Eds) Parasite communities: patterns and processes. London, UK: Chapman and Hall, pp. $157-195$.

Anderson, R.C. (2000): Nematoda Parasites of Vertebrates, their Development and Transmission. 2nd Edition, Walingford, UK, CABI Publishing, $650 \mathrm{pp}$.

AL-MoussaWI, A.A. (2010): First record in Iraq of Tanquaanomala (Linstow, 1904) from the dice snake, Natrix tessellata tessellata (Laurenti, 1768). Bull. Iraq Nat. Hist. Mus., 11(1): 27 - 38.

BAER, J.G. (1927): Monographie des Cestodes de la famille des Anoplocephalidae. Bull. Biol. France et Belgique, suppl. 10: 1 - 241 Baker, M.R. (1987): Synopsis of the Nematoda Parasitic in Amphibians and Reptiles. Occasional Papers in Biology. Volume 11. St. John's Newfoundland, Canada: Memorial University of Newfoundland, $325 \mathrm{pp}$.

Balozet, L., Callot, J. (1938): Trematodes de Tunisie. Trematodes de Rana ridibunda Pallas. Arch. I'Insti. Pasteur Tunis., 27: 18 - 30. Baran, I., Atatur, M.K. (1998): Herpetofauna of Turkey (Amphibia and Reptilia). Ankara (Ministry of Environment), 214 pp.

Baran, I., Ilgaz, C, Avcl, A., Kumlutas, Y., Olgun, K. (2012): Amphibians and Reptiles of Turkey. Ankara (TÜBITAK) 204 pp. (In Turkish)

BeverIDge, I. (1994): Family Anophalidae Cholodkovsky, 1902. In: Khall, L.F., Jones, A., Bray, R.A. (Eds) Keys to the cestode parasites of vertebrates. Wallingford, Oxon, UK: CAB İnternational, pp. $315-323$.

Birlik, S., Yildirimhan, H.S., Sumer, N., Kumlutas, Y., Ilgaz, C., Guclu, O., Durmus, S.H. (2015): The helminth fauna of Apathya cappadocica (Werner, 1902) (Anatolian Lizard) from Turkey. Helminthologia, 52(4): 310 - 315. DOI: 10.1515/helmin-2015-0049

Biserkov, V., Kostadinova, A. (1998): Intestinal helminth communities in the green lizard, Lacerta viridis, from Bulgaria. J. Helminthol., 72: 267 - 271. DOl: http://dx.doi.org/10.1017/ S0022149X00016540 
Bray, R., Gibson, D., Jones, A. (2008): Keys to the Trematoda. Vol. 3, London, UK, CAB International, 824 pp..

BuRSEY, C.R., Goldberg, S.R. (1991): Thubunaea intestinalis n. sp. (Nematoda: Spiruroidea) from Yarrow's spiny lizard, Sceloporus jarrovii (Iguanidac), from Arizona, U.S.A. T. Am. Microsc. Soc., 110: 269 - 278. DOI: 10.2307/3226661

Bursey, C.R., Rocha, C.F.D., Menezes, V.A., Ariani, C.V., VRCibradic, D. (2010): New species of Oochoristica (Cestoda; Linstowiidae) and other endoparasites of Trachylepis atlantica (Sauria: Scincidae) from Fernando de Noronha Island Brazil. Zootaxa, 2715: 45 - 54. DOI: 10.1654/4489.1

BurSey, C.R., Goldberg, S.R., Woolery, D.N. (1996): Oochoristica piankai sp. n. (Cestoda: Linstowiidae) and other helminths of Moloch Horridus (Sauria: Agamidae) from Australia. J. Helminthol. Soc. W., 63: $215-221$.

Carretero, M.A., Perera, A., Harris, D.J., Batista, V., Pinho, C. (2006): Spring diet and resource partitioning in an alpine lizard community from Morocco. Afr. Zool., 41(1): 113 - 122. DOI: http:// dx.doi.org/10.3377/1562-7020(2006)41[113:SDATPI]2.0.CO;2

Carretero, M.A., Roca, V., Larbes, S., Ferrero, A., Jorge, F. (2011): Intestinal helminth parasites of Wall Lizards, Podarcis vaucheri complex (Sauria: Lacertidae) from Algeria. J Herpetol., 45: 385 - 388. DOI: http://dx.doi.org/10.1670/10-118.1

Chabaud, A.G. (1975): Keys to the genera of the Order Spirurida Part 2. Spiruroidea, Habronematoidea and Acuarioidea. In: ANDERson, R.C., Chabaud, A.G., Wilmott, S. (Eds) ClH Keys to the Nematode Parasites of Vertebrates England: CAB, pp. $29-58$.

DAUOOD, K.S. (1974): Studies on the protozoan and trematode parasites of some amphibian from Nienava District, North Iraq. M. Sc. Thesis, Iraq, Mosul: Mosul University. ,

Daves, B. (1946): The Trematoda with Special Reference to British and other European forms. Cambridge, UK, Cambridge University Press, $644 \mathrm{pp}$.

Dollfus, R.P. (1951): Miscellania helminthologica maroccana. I. Quelques trematodes, cestodes and acanthocephales. Arch. Insti. Pasteur Maroc., 4: 104 - 229.

Dusen, S., Kumlutas, Y., Ilgaz, C., Yaka, H., Karadayı, F. (2013): Helminth Parasites of the Three Racerunner Lizards: Eremias pleskei Nikolsky, 1905 (Pleske's Racerunner-Transcaucasian Racerunner), Eremias strauchi Kessler, 1878 (Strauch's Racerunner) and Eremias suphani Basoglu and Hellmich, 1968 (Suphan Racerunner) collected from Eastern Part of Turkey. Helminthologia, 50(2): 108 - 111. DOI: 10.2478/s11687-013-0117-3

El Ayadi, M., Navarro, P., Lluch, J. (2003): Estudios preliminaries sobre la helmintofauna parasita de anuros de la provincia de Tetuan (Marruecos). Datos faunisticos. XII Bienal de la Real Sociedad Espanola de Historia Natural. Comunicaciones sobre Zoologia de Invertebrados No Artropodos. Spain.

Galdon, M.A., Roca, V., Barbosa, D., Carretero, M.A. (2006): Intestinal helminth communities of Podarcis bocagei and Podarcis carbonelli (Sauria: Lacertidae) in NW Portugal. Helminthologia, 43: 37 - 41. DOI: 10.2478/s11687-006-0008-y
Georgiev, B.B., Biserkov, V.Y., GenOt, T. (1986): In toto staining method for cestodes with iron acetocarmine. Helminthologia, 23: $279-281$.

GIBSON, D.I., BraY, R.A. (1994): The evolutionary expansion and host-parasite relationships of the Digenea. Int. J. Parasitol., 24: 1213-1226. DOI: 10.1016/0020-7519(94)90192-9

Guillen-Hernandez, S., Garcia-Prieto, L., Arizmendi-Espinosa, M.A. (2005): A new species of Oochoristica (Eucestoda: Cyclophyllidea) parasite of Ctenosaura pectinata (Reptilia: Iguanidae) from Oaxaca, Mexico. J. Parasitol., 91: 99 - 101. DOI: http://dx.doi. org/10.1645/GE-1118R.1

JoHRI, L.N. (1950): Report on cestodes collected in India and Burma. Indian J. Helminthol., 2: 23 - 34.

Gurelli, G., Gocmen, B., Ceetin-Dogan, T., Alpagut-Keskin, N. (2007): First record of Mesocestoides spp. Vaillant, 1863 Tetrathyridia (Cestoidea: Cyclophyllidae) in Anatolian lizard, Anatololacerta danfordi (Günther, 1876) in Turkey. N. West J. Zool., 3(2): 96 - 104 Holt, B.G., Lessard, M.K., BorregaArd, S.A., Fritz, M.B., ArauJo, D., Fabre, P.H., Graham, C.H., Gaves, G.R., Jonsson, K.A. (2013): An update of Wallaces's zoogeographic regions of the World. Science, 339: 74 - 78. DOI: 10.1126/science.1228282

HoRnero, M.J., Roca, V. (1992): Redescription of Skrjabinodon medinae (Galcia-Calvente, 1948) (Nematoda: Pharyngodonidae) from the cloaca of Podarcis pityusensis (Bosca, 1883) (Sauria: Lacertidae) of the Balearic Islands (Spain). Syst. Parasitol., 23: 31 - 35. DOI: $10.1007 / \mathrm{BF} 00008006$

Hughes, R.C. (1940): The genus Oochoristica Lühe, 1898. Am. Midl. Nat. J., 23: 368 - 380.

Ilgaz, C., Kumlutas, Y., Candan, K. (2016). A new locality record for Phoenicolacerta laevis (Gray, 1838) (Squamata: Lacertidae) in the Western Anatolia. Turk. J. Zool., 40: 129 - 135. DOI: 10.3906/ zoo-1412-11

INGLIS, W.G. (1968): Nematodes parasitic in Western Australian Frogs. Bull. Brit. Mus. (Natural History). Zoology, 16: 163 - 183.

InCEDOGAN, S., YILDIRIMHAN, S., BuRSEY, C.R. (2014): Helminth parasites of the ocellated skink, Chalcides ocellatus (Forskal,1775) (Scincidae) from Turkey. Comp. Parasitol., 81(2): 260 - 269. DOI: 10.1654/4708.1

Khotenovski, I.A. (1970): Family Pleurogenidae Looss, 1899. In: SkrJabin, K.I. (Eds) Trematodes of Animals and Man., Izd-vo Akademii nauk Moscow, 23: 139 - 306.

KIRIN, D. (2002): New data on the helminth fauna of Lacerta viridis Laurenti, 1768, and Podarcis muralis (Laulrenti, 1768) (Reptilia: Lacertidae) in Bulgaria. Acta Zool. Bulg., 54: 43 - 48.

LeVIN, J. (1992A): Parasites of the sand lizard (Lacerta agilis L.) in Poland. Acta Parasitol., 37: 19 - 24.

LeVIN, J. (1992B): Parasites of Lacerta vivipara Jacquin, 1787 in Poland. Acta Parasitol., 37: 79 - 82.

LUHE, M. (1898): Oochoristica nov. gen. Taeniadarum (Vorla"ufige Mitteilung). Zool. Anz., 21: 650 - 652.

MARTIN, J.E., RocA, V. (2004): Helminth infracommunities of Gallotia caesaris caesaris and Gallotia caesaris gomerae (Sauria: La- 
certidae) from the Canary Islands (Eastern Atlantic). J. Parasitol., 90: $266-270$.

Martin, J.E., RocA, V. (2005): Helminths of the Atlantic lizard, GalIotia atlantica (Reptilia: Lacertidae), in the Canary Islands (Eastern Atlantic): composition and structure of component communities. Acta Parasitol., 50: 85 - 89.

Martin, J.E., Llorente, G.A., Roca, V., Carretero, M.A., Montori, A., Santos, X., Romeu, R. (2005): Relationship between diet and helminths in Gallotia caesaris (Sauria: Lacertidae). Zoology, 108: 121 - 130. DOI: 10.1016/j.zool.2005.03.002

Mcallister, C.T., Matthew, B.C., Bursey, C.R., Stanley, E., Trauth, H.W., David, B.C. (2014): Six New Host Records for Mesocestoides sp. Tetrathyridia (Cestoidea: Cyclophyllidea) from Amphibians and Reptiles of Arkansas, U.S.A. Comp. Parasitol., 81(2): 278 - 283. DOI: http://dx.doi.org/10.1654/4685R.1

MegGitt, F.J. (1934): On some tapeworms of the bullsnake (Pityopis savi), with some remarks on the species of the genus Oochoristica (Cestoda). J. Parasitol., 20: 181 - 189.

Mihalca, A.D., Gherman, C., GhiRA, I., Cozma, V. (2007): Helminth parasites of reptiles (Reptilia) in Romania. Parasitol. Res., 101: 491 - 492. DOI: 10.1007/s00436-007-0486-y

Padgett, K.A., Boyce, W.M. (2004): Life history studies on two molecular strains of Mesocestoides (Cestoda: Mesocestoididae): Identification of sylvatic hosts and infectivity of immature life stages. J. Parasitol., 90(1): 108 - 114. DOI: http://dx.doi.org/10.1645/ GE-100R1

Petter, A.J., Quentin, J.C. (1976): ClH keys to the nematode parasites of vertebrates. No. 4 keys to genera of the Oxyuroidea, 1st ed. Commonwealth Agricultural Bureaux International, Farnham Royal, U.K., $30 \mathrm{pp}$.

RASHED, A.A. (2008): A new parasitic metacercaria from the land snail Monacha obstructa Pfeiffer 1842 with critical review on relevant metacercariae belonging to the genus Brachylaima Dujardin 1843. J. Egypt. Soc. Parasitol., 38: 483 - 500.

RAUSCH, R.L. (1994): Family Mesocestoididae Fuhrmann, 1907 In: Khall, L.F., Jones, A., Bray, R.A. (Eds) Keys to the Cestode Parasites of Vertebrates. International Institute of Parasitology, Institute of $\mathrm{CAB}$ International, University Press, Cambridge, pp. $309-314$

Roca, V., Lopez-Balaguer, E., Hornero, M.J. (1989): Helmintofauna de Podarcis hispanica (Steindachner, 1870) y Podarcis bocagei (Seoane, 1884) (Reptilia: Lacertidae) en el Cuadrante Noroccidental de la Península Ibérica. Rev. Ibér. Parasitol., 49: 127 - 135. Roca, V., Hornero, M.J. (1994): Helminth infracommunities of Podarcis pityusensis and Podarcis lilfordi (Sauria: Lacertidae) from the Balearic Islands (western Mediterranean Basin). Can. J. Zool., 72: $658-664$

RocA, V., LLUCH, J. (1988): L'helmintofaune des lacertidae (Reptilia) de la zone thermomediterraneenne de l'est de l'Espagne. Aspects ecologiques Vie Milieu, 38: 201 - 205.

Roca, V., Carretero, M.A., Marques, A., Barbosa, D., Galdon, M.A. (2006): Relationships between helminth communities and host traits in Podarcis bocagei and P. carbonelli from NW Portugal. Ita. J. Zool., 73(3): 213 - 217. DOI: 10.1080/11250000600727634

Roca, V., Jorge, F., Carretero, M.A. (2012): Synopsis of the helminth communities of the lacertid lizards from the Balearic and Canary Islands. Basic Applied Herpetology, 26: 107 - 116.

Roca, V., Jorge, F., Ilgaz, C., Kumlutas, Y., Durmus, S.H., CarRETERO, M.A. (2015a): The intestinal helminth community of the spiny-tailed lizard Darevskia rudis (Squamata,Lacertidae) from Northern Turkey. J. Helminthol., 90(2): 144 - 51 doi:10.1017/ S0022149X14000911

Roca, V., Jorge, F., Ilgaz, C., Kumlutas, Y., Durmus, S.H., CarreteRO, M.A. (2015b): Are the helminth communities from unisexual and bisexual lizards different? Evidence from gastrointestinal parasites of Darevskia spp. in Turkey. Acta Zool. Acad. Sci. Hung., 61(3): 279 - 288. DOI: 10.17109/AZH.61.3.6.2015

Roca, V., FerRagut, M.V. (1989): Helminthofauna del lagarto verdinegro, Lacerta schreiberi Bedriaga, 1878 (Reptilia: Lacertidae) del sistema central (Espana). Rev. Iber. Parasitol., 49: 291 - 300. RudolPHI, C. (1819): Entozoorum Synopsis, cui Accedunt manissa duplex et indices locupletissimi. Augusti Rücker, Berlin, Germany $811 \mathrm{pp}$.

Sanchis, V., Rolg, J.M., Carretero, M.A., Roca, V., Llorente, G.A. (2000): Host-parasite relationships of Zootoca vivipara (Sauria: Lacertidae) in the Pyrenees (North Spain). Folia Parasit., 47: 118 $-122$.

SAYGI, G., OLgUN, K. (1993): The nematode found in Dwarf Lizard (Lacerta parva) in Sivas province: Spauligodon. Turk. Parazitol. Derg., 17(1): $40-45$.

Schad, G.A., Kuntz, R.E., Wells, W.H. (1960): Nematode parasites from Turkish vertebrates. An annotated list. Can. J. Zool., 38: 949 $-963$.

SCHMIDT, G.D. (1986): Handbook of Tapeworm Identification. CRC Press Inc., Boca Raton, Florida 675 pp.

Sharpilo, V.P., Biserkov, V., Kostadinova, A., Behnke, J.M., Kuzmin, Y.I. (2001): Helminths of the sand lizard, Lacerta agilis (Reptilia, Lacertidae), in the Palaearctic: faunal diversity and spatial patterns of variation in the composition and structure of component communities. Parasitology, 123: 389 - 400.

SharpILO, V.P. (1976): Parasitic worms of reptiles in the fauna of SSSR.] Trudy Vsesoyuznogo Instituta Gel'mintologii. Izd. Naukova Dumka, Kiev, 286 pp. (In Russian).

SKARBILOVICH, T.S. (1948): Lecithodendriidae Odhner, 1911. Pages 337-590 /// K. I. Skrjabin, ed. Trematodi Zhivotnikh i Cheloveka. Vol. II. Akad. Nauk SSSR, Moscow.

Skruabin, K.I., Shikhobalova, N.P., Lagodovskaya, E.A. (1960): Oxyurata of animal and man. part I. Osnovynematodologii 8. Publ. House Acad. Sci. U.S.S.R., Moscow.

SkRYABIN, K.I., Sobolev, A.A. (1964): Spirurata of animals and man and the diseases caused by them. Part 2. Physalopteroidea. Osnovy nematodologii 12. Nauka, Moscow. 334 pp. (In Russian).

SpASSKII, A.A. (1951): Anoplocephalate tapeworms of domestic and wild animals. Academy of Sciences of the USSR, Moscow. 
Translated from Russian, 1961, The Israel Program for Scientivic Translations for the National Science Foundation, Washington, D. C. $783 \mathrm{pp}$.

Tamar, K., Carranza, S., Bosch, H., Sindaco, R., Moravec, J., Meiri, S. (2015): Hidden relationships and genetic diversity: Molecular phylogeny and phylogeography of the Levantine lizards of the genus Phoenicolacerta (Squamata: Lacertidae). Mol. Phylogenet. Evol., 91: 86 - 97. DOI:10.1016/j.ympev.2015.05.002

UETZ, P. (2015, June): The Reptile Database, http://www.reptile-database.org, accessed.

Wardle, R.A., Mcleod, J.A. (1952): The zoology of tapeworms. University of Minnesota Press. 780 pp.

Wittenberg, G.G. (1934): Studies on cestode genus Mesocestoides (with summaries in French, English and German). Arch. Zool. Ital., 20: 467 - 509.

Yamaguti, S. (1958): Systema Helminthum, Vol. I. Pts. 1 and 2, The Digenetic Trematodes of Vertebrates. Interscience Publ. Inc New York 1575 pp.

YamagutI, S. (1961): Systema Helminthum: The Nematodes of Vertebrates. Vol. III, Part II. Nematodes of Amphibians. Intersciences Publishers, London, England 679 pp.
Yamaguti, S. (1971): Synopsis of Digenetic Trematodes of Vertebrates, Vols. I and II. Keigaku Publ. Co., Tokyo 1774 pp.

YILDIRIMHAN, H.S., GoldBeRG, S.R., BuRSEY, C.R. (2006): Helminth parasites of the Caucasian agama, Laudakia caucasia, and the roughtail rock agama, Laudakia stellio (Squamata: Agamidae) from Turkey. Comp. Parasitol., 73: 257 - 262. DOI: 10.1654/4205.1 YILDIRIMHAN, H.S., SUMmER, N., YILMAZ, N. (2008): The helminth fauna of Hemidactylus turcicus (Mediterrenaen Gecko) (Linnaeus, 1758) from Hatay province. Acta Parasitol. Turcica, 32: 393 - 395 (In Turkish)

Yildirimhan, H.S., YiLmaz, N., InCEdogan, S. (2009): Helminth Fauna of the Anatolian Worm Lizard, Blanus strauchi (Bedriaga, 1884) from Hatay. Türk Parazitol. Derg., 33(4): 327 - 329.

YILDIRIMHAN, H.S., BuRsey, C.R., Altunel, F.N. (2011): Helminth parasites of the Balkan green lizard Lacerta trilineata Bedriaga 1886 from Bursa, Turkey. Turk. J. Zool. 35(4): 519 - 535. DOI:10.3906/ zoo-0910-1

Yorke, W., Maplestone, P.A. (1926): The nematode parasites of vertebrates. London, UK, J. and A. Churchill pp 536. 